\title{
PRODUCTION OF CAST POROUS METAL
}

\section{IZDELAVA POROZNIH KOVINSKIH ULITKOV}

\author{
Filip Radkovský, Václav Merta \\ VSB - Technical University of Ostrava, Faculty of Materials Science and Technology, Department of Metallurgy and Foundry Engineering, 17. \\ listopadu 15/2172, 70833 Ostrava-Poruba, Czech Republic \\ Prejem rokopisa - received: 2018-07-13; sprejem za objavo - accepted for publication: 2018-10-18
}

doi:10.17222/mit.2018.146

The article deals with the foundry methods of manufacturing porous metal; it is focused on the materials with a regular arrangement of internal cells. Currently, there are many fields dealing with the problem of porous metals by either optimizing the already known technologies, developing new ones or using porous metals. The production of a porous metal with a regular structure of cells and the possibility of its functional usage are the main subjects of this article. Due to their shapes, sizes and distribution of internal pores, cast porous metals exhibit various properties including reduced weight, sufficient strength, an ability to absorb impact energy, a possibility to conduct heat, etc., that allow a wide range of applications in the areas such as construction, transport or power engineering.

Keywords: porous metal, energy absorption, lost foam, deformation work

Članek opisuje livarske metode izdelave poroznih kovin. Osredotoča se na materiale s pravilno urejenostjo notranjih celic. Trenutno se na mnogih področjih ukvarjajo s problemi poroznih kovin, bodisi z optimizacijo že znanih tehnologij, razvojem novih, ali njihovo uporabo. Glavni predmet članka je izdelava poroznih kovin s pravilno strukturo celic in možnostjo njihove uporabe. Porozni ulitki imajo zaradi svoje značilne oblike, velikosti in porazdelitve por različne specifične lastnosti, vključno Z manjšo maso, zadovoljivo trdnostjo, sposobnostjo absorpcije udarne energije, prevajanja toplote itd. Vse to omogoča njihovo uporabo na različnih področjih, kot so konstrukcije, transport, inženiring prenosa energije in moči.

Ključne besede: porozne kovine, absorpcijska energija, ulivanje z izparljivimi modeli, deformacija

\section{INTRODUCTION}

The term of porous metal refers to a light, porous material with a cellular structure but with good mechanical properties. The porosity of these materials, i.e., the ratio of the vacant space to the total volume, ranges from $75 \%$ to $95 \%$. Cavities can be connected with open pores; in this case, the material is a porous metal with open cells. Cavities can also be mutually separated and then the material is a porous metal with closed cells. ${ }^{1,2}$

\subsection{Use of porous metals}

Metal foams find many applications in many industrial sectors (transport, aviation, defence, marine industry, power engineering and architecture). Foams are used as multifunctional materials for high-performance applications for civil, mechanical, chemical and biomedical engineering. ${ }^{3}$ Due to their low weight, high strength and the ability to absorb energy, porous-metal materials are suitable for the use, for example, in the deformation zones of conveying devices..$^{4,5}$

\subsection{Method of production}

A variety of methods and techniques for the production of porous-metal materials can be found in

*Corresponding author e-mail:

filip.radkovsky@vsb.cz practice. The production involving conventional casting processes used in foundries ensures an economic manufacture without the need to acquire expensive equipment. For the production of porous materials, the method of pouring a solid filler material with a liquid metal can be used as an example. After removing the filler material, the pores become structured. The size and shape of these castings are defined on the basis of the properties, at given process repeatability and in compliance with the process and production conditions. ${ }^{6}$ The defined properties of these modern materials are crucial for the other applications. ${ }^{7}$

\section{EXPERIMENTAL PART}

The experiment was focused on the production of metal foams with a regular structure and the testing of their mechanical properties. For the production of samples, the lost-foam method, i.e., the investment casting process was used. This is a widely used method for the manufacture of precision castings. For the manufacture of the pattern, expanded polystyrene (EPS) was used as a material suitable for the lost-foam method and also as a material fairly flexible for the manual manufacture of the pattern. The dimensions of the grids were $(52 \times 52 \times 6) \mathrm{mm}$ and the overall dimensions of the pattern were $(52 \times 52 \times 42) \mathrm{mm}$. The pattern consisted of 


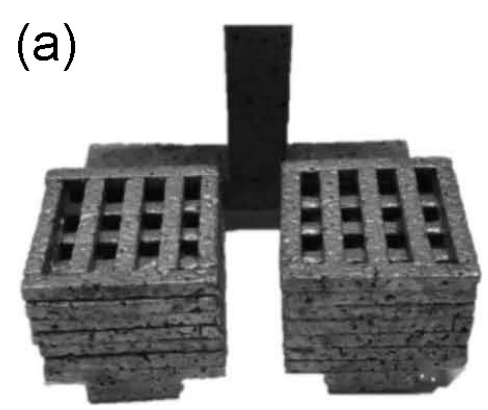

Figure 1: a) casting, b) machined sample, c) compressed sample (b)

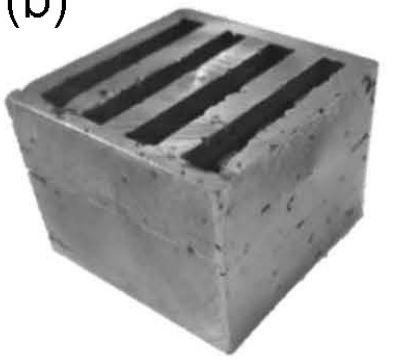

(c)

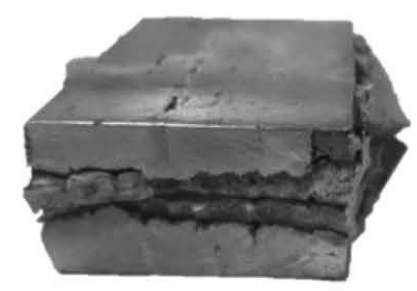

seven floors/grids that were glued together and equipped with a grating system.

The pattern together with the grating system was dipped in a fireproof coating of the FOUNDRYLAC $\mathrm{ZBM} / 365$ type. The cast material was aluminium alloy AlSi11, which is suitable for the production of thinwalled and shape-complicated castings. The alloy was molten in an electric resistance furnace (LAC 80/13). For a better alloy fluidity, higher casting temperatures were chosen, e.g., $750{ }^{\circ} \mathrm{C}$. The molten metal was poured directly on the pattern, which was placed in a flask and filled with dry quartz-based sand without a binder and compacted with vibration. The casting of the porous metal with the grating system is shown in Figure 1a.

\section{RESULTS}

All the samples with the dimensions of $(52 \times 52 \times$ 42) $\mathrm{mm}$ were subjected to a pressure test. A total of 20 porous-metal samples with a regular structure were tested. The tests were carried out at company VÍTKOVICE TESTING CENTER s.r.o. (Ltd.), a member of the VÍTKOVICE MACHINERY GROUP. Pressure tests were carried out on a Zwick Z600 machine with an advancing speed of $10 \mathrm{~mm} / \mathrm{min}$. A sample before and after the pressure test is shown in Figures $\mathbf{1 b}$ and 1c.

The castings manufactured with the lost-foam method were tested to investigate the material performance at constant loading and different deformation curves were determined. Several dozens of samples were measured. Selected values obtained with the pressure tests are given in Table $\mathbf{1}$. Using the calculations of triangles and cuboids for the potential, deformation curves (the area under a curve) and the values of the strain energy, i.e., deformation work (J) were calculated.

\section{DISCUSSION}

It is clear from the results of the pressure tests that Sample no. 8 reached the highest compression strength $(354 \mathrm{kN})$ and, at the same time, it exhibited the highest deformation $(31.7 \mathrm{~mm})$. The highest values of deformation were found for sample no. $13(3872 \mathrm{~J})$; its compression strength was slightly above the average of all the samples. The average of the maximum compression-strength values for the tested samples was $272.50 \mathrm{kN}$. Deformation curves for different samples showed a similar trend and for this reason, only the

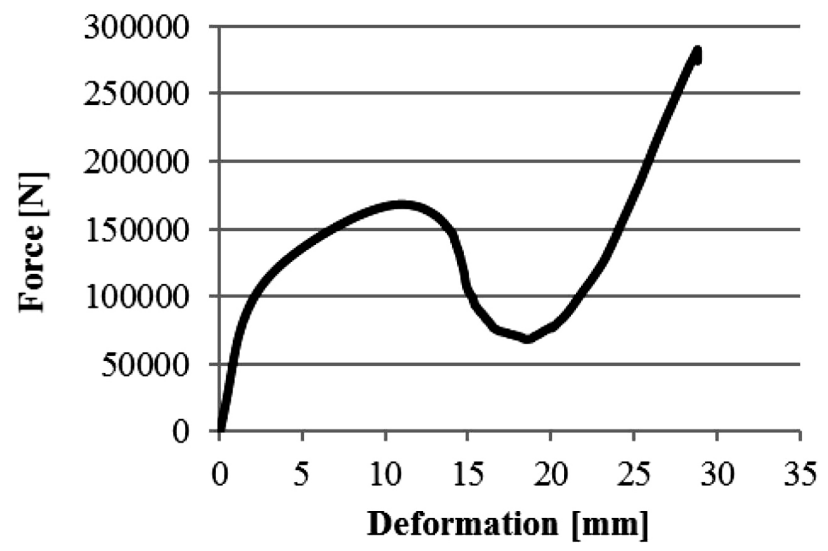

Figure 2: Force vs. stress curve

Table 1: Results of the pressure tests of individual samples

\begin{tabular}{|c|c|c|c|c|c|}
\hline Sample number & $\begin{array}{c}\text { Casting temperature } \\
\left({ }^{\circ} \mathrm{C}\right)\end{array}$ & $\begin{array}{c}\text { Real dimensions after } \\
\text { machining }(\mathrm{mm})\end{array}$ & $\begin{array}{c}\text { Max. compression } \\
\text { strength }(\mathrm{kN})\end{array}$ & $\begin{array}{c}\text { Max. deformation } \\
(\mathrm{mm})\end{array}$ & $\begin{array}{c}\text { Deformation work } \\
(\mathrm{J})\end{array}$ \\
\hline 1 & 793 & $49.7 \times 49.3 \times 38.3$ & 254 & 29.1 & 2962 \\
\hline 5 & 792 & $49.3 \times 49.6 \times 38.3$ & 276 & 28.9 & 3027 \\
\hline 7 & 807 & $49.8 \times 49.0 \times 38.0$ & 277 & 30.6 & 2831 \\
\hline 8 & 807 & $49.7 \times 48.8 \times 38.4$ & 354 & 31.7 & 3340 \\
\hline 9 & 795 & $48.8 \times 48.0 \times 38.4$ & 268 & 29.1 & 3010 \\
\hline 13 & 807 & $48.0 \times 48.8 \times 38.4$ & 283 & 28.8 & 3872 \\
\hline 16 & 807 & $49.4 \times 48.3 \times 38.6$ & 325 & 29.9 & 3486 \\
\hline 19 & 808 & $48.5 \times 49.5 \times 38.2$ & 270 & 27.7 & 3205 \\
\hline
\end{tabular}


graph for sample no. 13 is shown as a representative example, Figure 2.

\section{CONCLUSIONS}

The dimensions of $(52 \times 52 \times 42) \mathrm{mm}$ were chosen for the polystyrene pattern. These samples were pressure tested. The average value of the maximum compression strength was $272.50 \mathrm{kN}$. Individual values of the strain energy were calculated for the total areas under individual deformation curves. The average value of the strain energy was $3150 \mathrm{~J}$. Due to the obtained values of the strain energy, this porous metal can be recommended for further development with respect to applications in transportation deformation zones. The potential of this modern material to absorb a large amount of impact energy is obvious from the obtained results, but it is still difficult to find the right shape for a specific application.

\section{Acknowledgment}

The contribution was carried out with the support of the Technology Agency of the Czech Republic -
TH02020668, TA02011333 and project of "Student Grant Competition" numbers SP2019/148 and SP2019/43.

\section{REFERENCES}

${ }^{1}$ https://www.scribd.com/presentation/67448227/Metal-Foam, 08.07.2018

${ }^{2}$ L. J. Gibson, M.-F. Ashby, Cellular solids - Structures and properties, Cambridge university press, 1997, 515

${ }^{3}$ F. García-Moreno, Commercial Applications of Metal Foams: Their Properties and Production, Materials, 85 (2016) 9, doi:10.3390/ ma9020085

${ }^{4}$ Y. Schmitt, J. L. Pierrot, J. Arbaoui, F. X. Royer, Mechanical properties of a cellular composite: comparison with other structures, Archives of Metallurgy and Materials, 50 (2005) 1, 111-117

${ }^{5}$ P. Kordzikowski, M. Janus-Michalska, R. B. Pecherski, Specification of energy-based criterion of elastic limit states for cellular materials, Archives of Metallurgy and Materials, 50 (2005) 3, 619-634

${ }^{6}$ P. Lichý, T. Elbel, I. Kroupová, F. Radkovský, Preparation and evaluation of properties of cast metallic foams with regular inner structure, Archives of Metallurgy and Materials, 42 (2017) 3, 1643-1646, doi:10.1515/amm-2017-0251

${ }^{7} \mathrm{~J}$. Banhart, Manufacture, characterisation and application of cellular metals and metal foams, Progress in Materials Science, 46 (2001) 6, 559-632, doi:10.1016/S0079-6425(00)00002-5 